on June 26. The members next proceed to Stockholm by special sleeping-car trains, where the opening address will be given by the Crown Prince of Sweden. A number of very attractive tours has been arranged, including one to Finland by aeroplane or boat. The closing session will be held in Oslo on July 8. The Conference Bureau will assist those who desire to pay a visit to any holiday resort. A large number of rooms have been reserved in the smaller hotels at prices which are stated to be far below the usual Continental level. The exchange also is in favour of sterling. Further details can be obtained from the offices of the World Power Conference, 63 Lincoln's Inn Fields, London, W.C.2.

\section{Fifth Pacific Science Congress}

Ar the invitation of the Government of Canada and under the auspices of the Canadian National Research Council, the Pacific Science Association will hold the fifth Pacific Science Congress, for the study of Pacific problems, in Victoria and Vancouver, B.C., Canada, on June 1-14. It is expected that some thirty countries bordering on the Pacific Ocean will be represented at the Congress by four to six hundred men of science. The president of the Executive Committee of the Congress will be Dr. H. M. Tory, president of the National Research Council of Canada and director of the National Research Laboratories. The Congress will open at Victoria on June 1, where sessions will be held until June 3. On June 4, it will proceed to Vancouver, where further sessions will be held until June 14. A postCongress tour has also been arranged from June 14 until June 19, when it will terminate at Calgary. The Congress will work in two divisions: Biological Sciences, under the chairmanship of Prof. C. McLean Fraser, professor of zoology at the University of British Columbia, Vancouver, and Physical Sciences, under the chairmanship of Prof. R. W. Brock, professor of geology and geography at the University of British Columbia. The secretary of the Congress is Mr. S. J. Cook of the National Research Council, whose address, in connexion with the Congress, is Hotel Vancouver, Vancouver, B.C., Canada.

\section{Announcements}

THE King has been pleased to appoint Sir William Cecil Dampier, fellow and sometime senior tutor of Trinity College, Cambridge, to be one of the Development Commissioners, in succession to the late Mr. Vaughan Nash.

By an order of the Committee of Privy Council, Sir Thomas Lewis, director of the Department of Clinical Research in University College Hospital, London, has been appointed a member of the Medical Research Council in succession to Prof. J. J. R. Macleod, regius professor of physiology in the University of Aberdeen.

The Melchett Medal for 1933 of the Institute of Fuel has been awarded to Sir John Cadman, chairman of the Anglo-Persian Oil Co., Ltd., and the Iraq Petroleum Company. The medal is an annual award for "original research or professional, administrative, or constructive work of an outstanding character, involving the scientific preparation or use of fuel."

IN view of certain changes in the administration of the Ministry of Agriculture of Brazil, the Directoria de Meteorologia will henceforth be entitled the "Instituto de Meteorologia, Hidrometria E Ecologia Agricola". Mr. R. P. Xavier retired from the position of director of the Brazilian Meteorological Service on March 6, and has been succeeded by Mr. C. de A. Martins Costa.

IT is announced by the Paris correspondent of the Times that the French Government has created a chair of mathematical physics at the Collège de France for Prof. A. Einstein. Special legislation was necessary and a Bill was prepared by the Ministry of Education and passed rapidly through the necessary stages in the Chamber of Deputies before the Easter. recess. A few days earlier, the Madrid correspondent of the Times stated that the Spanish Minister of Education had announced the acceptance by Prof. Einstein of a chair in Spain and that, while the Government had made no precise conditions, it was thought Prof. Einstein would go to Madrid.

The forty-fourth Congress of the Royal Sanitary Institute will be held at Blackpool on June 17-24, under the presidency of the Right Hon. Lord CozensHardy. The Congress will be divided into the following sections: Preventive Medicine; Architecture, Town Planning and Engineering; Maternity, Child Welfare and School Hygiene; Veterinary Hygiene; National Health Insurance; Hygiene of Food. Conferences of representatives of sanitary authorities, medical officers of health, engineers and surveyors, sanitary inspectors and health visitors will also be held in connexion with the Congress. Particulars can be obtained from the secretary of the Institute, Mr. J. W. Dudley Robinson, 90, Buckingham Palace Road, S.W.l.

Applicatrons are invited for the following appointments, on or before the dates mentioned :-A junior assistant in the surgical unit of the Welsh Nationa] School of Medicine (University of Wales), The Parade, Cardiff-The Secretary (April 25). A lecturer in civil engineering and building at the Portsmouth Municipal College-The Registrar (May 5). A dairy bacteriologist in the Department of Agriculture and Horticulture of the University of Bristol-A. W. Ling, Agricultural Advisory Office, 22, Berkeley Square, Bristol 8 (May 6). An assistant lecturer in engineering at the Cardiff Technical College-The Director of Education, City Hall, Cardiff (May 6). A lecturer in electrical engineering at the Chelmsford School of Art and Technology-The Clerk to the Governors (May 8). A lecturer in pathology to dental students in the University and pathologist to the Queen's Hospital, Birmingham-The Secretary, The University, Birmingham (May 15). A demonstrator in physiology at St. Thomas's Hospital Medical School (University of London)-The Dean of the Medical School (May 27). 